ORIGINAL ARTILE

AFRICAN JOURNAL OF CLINICAL AND EXPERIMENTAL MICROBIOLOGY JULY 2018 ISBN 1595-689X VOL19 No.3

AJCEM/1831

COPYRIGHT 2018 https://dx.doi.org/10.4314/ajcem.v19i3.10

http://www.ajol.info/journals/ajcem

AFR. J. CLN. EXPER. MICROBIOL. 19 (3): -221-228

\title{
ANTIFUNGAL PROPERTIES OF METHANOLIC EXTRACTS OF SOME MEDICAL PLANTS IN ENUGU, SOUTH EAST NIGERIA
}

\author{
Onyemelukwe', N., Ndam², P., Ogboi ${ }^{3}$, S. J., Maduakor ${ }^{4}$, U., Nwakile ${ }^{5}$ D. \\ 1,2,3,4,5Department of Medical Laboratory Sciences, Faculty of Health Sciences and technology, College of Medicine, \\ University of Nigeria, Enugu Campus
}

Correspondene: Ogboi Sonny Johnbull, Department of Medical Laboratory Sciences, Faculty of Health Sciences and technology, College of Medicine, University of Nigeria, Enugu Campus, Nigeria. Email address: ogboijb@yahoo.com

\section{ABSTRACT}

Objective: The current study evaluated the anti-fungal activities of methanolic extracts of the leaves and fruits of some medicinal plants of health value in Enugu, southeast Nigeria.

Materials and methods: Volumes of the different extracts into molten Sabouraud Dextrose Agar to make up for concentrations of $25 \mathrm{mg} / \mathrm{ml}, 50 \mathrm{mg} / \mathrm{ml}$ and $100 \mathrm{mg} / \mathrm{ml}$ respectively. Concentrations of $125 \mu \mathrm{g} / \mathrm{ml}, 250 \mu \mathrm{g} / \mathrm{ml}$ and $500 \mu \mathrm{g} / \mathrm{ml} \mathrm{of}$ Miconazole were incorporated to serve as a positive control while $0.5 \mathrm{ml}$ of DMSO served as a negative control. The plants extracts employed were from Azadirachta indica (Neem), Anacardium occidentale (Cashew), Euphorbia hirta (Asthma weed),Jatropha curcas (Physic nut), Acantus montanus (Mountain thistle) and Picralima nitida (òsúigwe in Igbo). A $2 \mathrm{~mm}$ agar disc cut out from the margin of actively growing cultures of each dermatophyte (Trichophyton soudanense, T.mentagrophytes, Cladosporium sp, T.rubrum and Fusarium sp) were inoculated on the agar plates containing varying concentrations of the different plant extracts, the standard antifungal agent and negative control in triplicates and incubated at $28^{\circ} \mathrm{C}$.

Results: All the extracts exhibited antifungal activities of varying degrees with radial growth inhibitions (RGIs) ranging from $0-0.45 \mathrm{~mm}$ radius. Fifty percent $(50 \%)$ of the plants extracts comprising of Picralima nitida, Euphorbia hirta and Acantus montanus exhibited complete inhibition at $100 \mathrm{mg} / \mathrm{ml}$ against all the clinical isolates under investigation $(\mathrm{p}<0.05)$ . Picralima nitida seed was the only plant extract with complete inhibition at $25 \mathrm{mg} / \mathrm{ml}$ against T.soudanense and T.rubrum. Picralima nitida was the closest in activity to miconazole. Azadirachta indica (Neem) did not exhibit complete inhibition against any of the clinical isolates at $100 \mathrm{mg} / \mathrm{ml}$ yet exhibited a significantly lower RGI at the lowest concentration of 25 $\mathrm{mg} / \mathrm{ml}$ better than others.

Conclusion: Antifungal activities showed that leaves extract of fruits plants against the clinical isolates are good source of medicinal applications

Key words: Antifungal agents, medical plants, Enugu, Nigeria.

\section{PROPRIÉTÉS ANTIFONGIQUES D'EXTRAITS MÉTHANOLIQUES DE CERTAINES PLANTES MÉDICALES À ENUGU, AU SUD-EST DE NIGERIA}

\author{
Onyemelukwe', N., Ndam², P., Ogboi ${ }^{3}$, S. J., Maduakor ${ }^{4}$, U., Nwakile ${ }^{5}$ D.
}

\author{
1,2,3,4,55 Ministère des sciences de laboratoire médical, Faculté des Sciences de la santé et de la technologie, Faculté de \\ médecine de l'Université du Nigeria Enugu,
}

Correspondene Ogboi Campus : Sonny Johnbull, Ministère de sciences de laboratoire médical, Faculté des Sciences de la santé et de la technologie, Faculté de médecine de l'Université du Nigéria, Enugu, Nigéria. Campus Adresse e-mail : ogboijb@yahoo.com

\section{RÉSUMÉ}

Objectif: La présente étude a évalué les activités anti-fongiques des extraits méthanoliques des feuilles et fruits de certaines plantes médicinales de valeur santé à Enugu, au sud-est du Nigeria.

Matériel et méthodes: Volumes des différents extraits dans molten Sabouraud Dextrose Agar pour compenser pour les concentrations de $25 \mathrm{mg} / \mathrm{ml}, 50 \mathrm{mg} / \mathrm{ml}$ et $100 \mathrm{mg} / \mathrm{ml}$ respectivement. Les concentrations de $125 \mu \mathrm{g} / \mathrm{ml}, 250 \mu \mathrm{g} / \mathrm{ml} \mathrm{et} 500 \mu \mathrm{g} / \mathrm{ml}$ de miconazole ont été intégrés pour servir comme contrôle positif alors que $0,5 \mathrm{ml}$ de DMSO a servi de témoin négatif. Les extraits de plantes utilisés étaient d'Azadirachta indica (neem), noix de cajou (Anacardium occidentale), Euphorbia hirta (asthme), Jatropha curcas (pourghère),Acantus montanus (chardon de montagne) et de Picralima nitida (òsúigwe en Igbo). Un disque de $2 \mathrm{~mm}$ d'agar coupé à partir de la marge de croissance active, les cultures de chaque (dermatophytes Trichophyton soudanense, T. mentagrophytes, Cladosporium sp, T.rubrum et Fusarium sp) ont été inoculés sur les géloses contenant des concentrations variables des différents extraits de plantes, la norme agent antifongique et contrôle négatif en triplicats et incubées à $28^{\circ} \mathrm{C}$.

Copyright (O2017 AJCEM. This work is licensed under the Creative Commons Attribution 4.0 International License CC-BY 
Résultats: Tous les extraits de l'exposé des activités antifongiques avec divers degrés d'inhibitions de la croissance radiale (RGIs) allant de 0-0,45 $\mathrm{mm}$ de rayon.

Cinquante pour cent $(50 \%)$ des extraits de plantes comprenant de Picralima nitida, Euphorbia hirta et Acantus montanus présentaient une inhibition complète à $100 \mathrm{mg} / \mathrm{ml}$ contre tous les isolats cliniques soumis à l'enquête $(\mathrm{p}<0,05)$.

Picralima nitida semence a été le seul extrait de plantes avec une inhibition complète à $25 \mathrm{mg} / \mathrm{ml}$ contre T.soudanense et T.rubrum. Picralima nitida était la plus proche de l'activité pour le miconazole. Azadirachta indica (neem) n'ont pas d'inhibition complète à l'égard d'aucun des isolats cliniques à $100 \mathrm{mg} / \mathrm{ml}$ mais montrent un souci nettement inférieur à la plus faible concentration de $25 \mathrm{mg} / \mathrm{ml}$ mieux que d'autres.

Conclusion: Activités antifongique a montré que l'extrait de feuilles de fruits plantes contre les isolats cliniques sont une bonne source d'applications médicinales

Mots clés: antifongiques, plantes médicinales, Enugu, Nigéria.

\section{INTRODUCTION}

The increasing incidence of growing resistance to antifungal agents despite the intensive use of antifungal drugs in the treatment of fungal infection [1], has become a great health challenge. However, there has been some claims by the traditional healers that some medicinal plants are more efficient in the treatment of infectious diseases than synthetic antibiotics. Medicinal plants have been practiced for centuries as remedies for human diseases as they incorporate elements of therapeutic value. At that place are numerous plant natural products which have antifungal, antibacterial and antiprotozoal activities that could be used either systemically or locally [2]. Medicinal plants are considered to be an important source of new chemical substances with possible therapeutic effects [3]. The World Health Organization (WHO) estimates that up to $85 \%$ of people still rely primarily on traditional remedies such as herbaceous plants for their medicine [4]. Traditional healing plays an integral role in black African culture as it provides health care needs for a large majority of the society [5]. Presently, there is growing awareness of scientific and medicinal plants in the health care system of many developing countries [6]. In Nigeria, there is a rich tradition in the use of herbal plant products for the treatment of several ailments. Plants such as Euphorbia hirta (Asthma weed), Anacardium occidentale (Cashew), Picralima nitida (Òsúigwe), Jatropha cucas (Physic nut), Azadirachta indica (Neem) and Acantus montanus (Mountain thistle) have been used by the people within the Enugu metropolis for the local treatment of skin diseases because of their effectiveness, availability and cost effectiveness.

Furthermore, nature has bestowed a very rich botanical wealth of vegetation, and a large number of diverse types of plants grow in different parts of the country. They constitute the richest source of drugs for traditional systems of medicine, modern medicines, food supplements [7]. The increasing prevalence of serious mycoses coupled with the frequent use of the available antifungal drugs has resulted in rising resistance of fungal pathogens to antifungal agents. However, these topical drugs are generally ineffective against fungal infections of the nails due to their inability to penetrate the entire nail unit and eradicate the infection. The increasing prevalence of serious mycoses coupled with the frequent use of antifungal drugs currently available has resulted in rising resistance of fungal pathogens to antifungal agents. There is, therefore, a need for new broad-spectrum antifungal agents that can be used empirically in immune compromised patients, organ transplant patient, and other challenging situations. Use of herbal medicine in the treatment of infection with microorganisms predates the introduction of antibiotics [8]. Herbs are widely exploited in the traditional medicine and their curative potentials are well documented too, as well as representing a rich source of antimicrobial agents [9], with many of them readily available in rural areas at a relatively cheaper price. Medicinal plants extracts are promising as alternative or complementary control means because of their antimicrobial activity, non-phytotoxicity, as well as biodegradability properties [10].

Considering the vast potential of plants materials in the health care and the challenges in the management of fungal infections, this current study was designed to evaluate the antifungal properties of methanolic extracts of some traditional medicinal plants in Enugu, South East, Nigeria and their phytochemistry properties in order to reformulate the existing antifungals that are essential for improving patient management.

\section{MATERIALS AND METHODS}

Preparation of Plant Materials

Fresh leaves of the plants, Azadirachta indica (Neem), Anacardium occidentale (cashew). Euphorbia hirta (Asthma weed), Jatropha curcas (Physic nut), Acantus montanus (Mountain thistle) and the Picralima nitda (Òsúigwe) Seeds \& Rind were collected within the Enugu metropolis and authenticated in the Botany Department of the University of Nigeria, Nsukka. They were washed under running tap water and air dried in room for 5 days (for the leaves) and 12 days (for the seeds and rind).The materials were ground into fine powder and stored in labelled air tight containers.

\section{Preparation of Crude Extracts}

$100 \mathrm{~g}$ of each of the powdered form of the plant materials was exhaustively extracted by Soxhlet extraction method [11], using absolute methanol at $30^{\circ} \mathrm{C}$.

\section{Preparation of fungal isolates}

Microscopically identified isolates of Trichophyton soudanense, T. mentagrophytes, T. rubrum, Cladosporum sp and Fusarium sp, were obtained 
from the Mycology Laboratory of the University of Nigeria Teaching Hospital, Ituku-Ozalla,Enugu. The isolates were subcultured in Sabouraud Dextrose Agar (SDA) to get pure cultures. Pure cultures were prepared in slanted cultures, stored in MacCartney bottles and kept at $2-8{ }^{\circ} \mathrm{C}$ for further experimental purposes.

\section{Determination of Antifungal Activities}

Reconstitution of plant extracts

A stock concentration was reconstituted by weighing $2 \mathrm{~g}$ of the individual plant residue by adding $1 \mathrm{ml}$ of DMSO to it in a test tube to make a concentration of $2 \mathrm{~g} / \mathrm{ml}(2000 \mathrm{mg} / \mathrm{ml})$.

Preparation of molten SDA plates containing the extract

The agar plate method was adopted as described [12].

\section{Culture Process}

The Culture medium of the different concentrations was inoculated with $2 \mathrm{~mm}$ agar disc cut out from the margin of the actively growing culture of the dermatophyte. This was carried out in triplicates and incubated at $28{ }^{\circ} \mathrm{C}$, with controls run concurrently. The radial growth was measured daily for 4 days and the average reading taken for the test, positive and negative controls.

Percentage radial growth inhibition was calculated by employing the following formula:

Percent inhibition $=\mathrm{C}-\mathrm{T} \div \mathrm{C} \times 100$ [13]. Where, $\mathrm{C}=$ Radial growth of negative control; $\mathrm{T}=$ Radial growth of the test

\section{Column Chromatography}

This was done using n-haxane, chloroform and ethyl acetate based on increasing polarity [14].

\section{Phytochemical Analysis}

The phytochemical analysis of fractionated Picralima nitida seed extract was carried out using standard methods [15].

Other test analysis for alkaloids, flavonoids, steroids and terpenoids, saponins, tannins carbohydrate, glycosides, resins (Precipitation test), proteins, fats and oil were carried using standard methods.

\section{Data analysis}

All generated data were subjected to statistical analysis using a one-way analysis of variance (ANOVA), followed by Dunnetts test (multiple comparison post-test) at $\mathrm{p}<0.05$.

\section{RESULTS}

Antifungal activities of the methanolic extracts of six medicinal plants were determined against five clinical isolates of fungi species. Miconazole nitrate was used as the standard for comparing the plant's extract. In Table 1, Miconazole nitrate at $500 \mu \mathrm{m} / \mathrm{ml}$ had the highest antifungal effect on the growth of
Cladosporium sp by inhibiting it completely with a percentage radial growth inhibition (PRGI) of $100 \%$. Picralima nitida seed extract exhibited the highest antifungal effect with all the three concentrations (Tables 2 and 3).

TABLE 1: PERCENTAGE RADIAL GROWTH INHIBITION OF POSITIVE CONTROL ANTIFUNGAL AGENT (MICONAZOLE) AGAINST FUNGAL ISOLATES

\begin{tabular}{|c|c|c|c|}
\hline \multirow[t]{2}{*}{ Fungal isolates } & \multicolumn{2}{|c|}{$\begin{array}{l}\text { Concentration of } \\
\text { nitrate }\end{array}$} & \multirow{2}{*}{$\begin{array}{l}\text { Miconazole } \\
500 \mu \mathrm{g} / \mathrm{ml}\end{array}$} \\
\hline & $\begin{array}{l}125 \\
\mu \mathrm{g} / \mathrm{ml}\end{array}$ & $\begin{array}{l}250 \\
\mu \mathrm{g} / \mathrm{ml}\end{array}$ & \\
\hline T.soudanense & $89.2 \%$ & $90 \%$ & $93.8 \%$ \\
\hline T.mentagrophytes & $75 \%$ & $78 \%$ & $85 \%$ \\
\hline Cladosporium $\mathrm{sp}$ & $86.7 \%$ & $95 \%$ & $100 \%$ \\
\hline T.rubrum & $94 \%$ & $95 \%$ & $98 \%$ \\
\hline Fusarium $\mathrm{sp}$ & $82.9 \%$ & $75.3 \%$ & $95.3 \%$ \\
\hline
\end{tabular}

TABLE 2: PERCENTAGE RADIAL GROWTH INHIBITION OF PICRALIMA NITIDA SEED EXTRACT AGAINST FUNGAL ISOLATES

\begin{tabular}{llcc}
\hline Fungal Isolates & \multicolumn{3}{l}{ Concentrations of extracts } \\
& 25 & $50 \mathrm{mg} / \mathrm{ml}$ & $100 \mathrm{mg} / \mathrm{ml}$ \\
& $\mathrm{mg} / \mathrm{ml}$ & \multicolumn{3}{l}{ Radial Growth inhibition } \\
& $100 \%$ & $100 \%$ & $100 \%$ \\
T.soudanense & $90 \%$ & $100 \%$ & $100 \%$ \\
T.mentagrophytes & 90 & $95 \%$ & $100 \%$ \\
Cladosporium sp & $91.7 \%$ & $100 \%$ & $100 \%$ \\
T.rubrum & $100 \%$ & $100 \%$ & $100 \%$ \\
Fusarium sp & $94.1 \%$ & & \\
\hline
\end{tabular}

TABLE 3: PERCENTAGE RADIAL GROWTH INHIBITION OF PICRALIMA NITIDA SEED FRACTIONS AGAINST FUNGAL ISOLATES

\begin{tabular}{|c|c|c|c|}
\hline Fungal Isolates & $\begin{array}{l}\text { Hexane } \\
\text { fraction } \\
(100 \\
\mathrm{mg} / \mathrm{ml})\end{array}$ & $\begin{array}{l}\text { Chloroform } \\
\text { fraction } \\
(100 \mathrm{mg} / \mathrm{ml})\end{array}$ & $\begin{array}{l}\text { Ethylether } \\
\text { fraction } \\
(100 \\
\mathrm{mg} / \mathrm{ml})\end{array}$ \\
\hline & $\begin{array}{l}\text { Radial } \\
\text { growth }\end{array}$ & Inhibition & \\
\hline T.soudanense & $55 \%$ & $77.1 \%$ & $26.7 \%$ \\
\hline T.mentagrophytes & $-33.3 \%$ & $25 \%$ & $-66.7 \%$ \\
\hline Cladosporium sp & $25 \%$ & $50 \%$ & $-50 \%$ \\
\hline T.rubrum & $35.7 \%$ & $88.6 \%$ & $57.1 \%$ \\
\hline Fusarium sp & $-14.3 \%$ & $83.3 \%$ & $0 \%$ \\
\hline
\end{tabular}

At $100 \mathrm{mg} / \mathrm{ml}$ the extract inhibited completely all the investigated isolates with PRGI of $100 \%$. At 50 $\mathrm{mg} / \mathrm{ml}$, there was complete inhibition against all isolates except against Cladosporium spp. and at 25 $\mathrm{mg} / \mathrm{ml}$ it inhibited completely T.soudanense and T.rubrum. The inhibitions exhibited by T.mentagrophytes, Cladosporium spp. and Fusarium spp. were, however, significant. 
T.soudanense and T.rubrum appeared to be the most sensitive of the fungi under investigation. This was followed by T.mentagrophytes and Fusarium spp. with a PRGI of $90-100 \%$. Cladosporium spp. with a PRGI of $91.7-100 \%$ appeared to be the least sensitive. The inhibition range of Picralima nitida seed extract for all the isolates was $90-100 \%$. There was no inhibition observed in the negative control. The PRGIs for the antifungal activities of Picralima nitida seed extract at $25 \mathrm{mg} / \mathrm{ml}, 50 \mathrm{mg} / \mathrm{ml}$ and 100 $\mathrm{mg} / \mathrm{ml}$, respectively were significant $(\mathrm{P}<0.05)$ compared with the standard.

The phytochemistry of the chloroform fraction of Picralima nitida seed revealed the presence of flavonoids, alkaloids, and terpenoids (Table 3). The highest antifungal effect was exhibited by Chloroform fraction with a PRGI of $88.6 \%$ against T.rubrum. All the fungi under investigation appeared sensitive to the chloroform extract. Ethyl ether fraction had a lesser antifungal effect on the experimental isolates. There was a significant difference of $(p<0.05)$ in the treatment of chloroform fraction against control.

From Table 4, Picralima nitida rind extract had its highest antifungal effect at $100 \mathrm{mg} / \mathrm{ml}$ by inhibiting completely all the investigated isolates with a PRGI of $100 \%$. RGs of $0.03 \pm 0.03 \mathrm{~mm}$ to $0.1 \pm 0.05 \mathrm{~mm}$ at 25 $\mathrm{mg} / \mathrm{ml}$ and $0.03 \pm 0.03 \mathrm{~mm}$ to $0.05 \pm 0.05 \mathrm{~mm}$ at 50 $\mathrm{mg} / \mathrm{ml}$ were observed for all the isolates. The activities of Picralima nitida rind at these concentrations show a significant difference $(\mathrm{p}<$ $0.05)$ compared to the activities of the standard antifungal agent. Table 5 shows that Azadirachta indica (Neem) seed extract did not inhibit any of the fungi completely at its highest concentration of 100 $\mathrm{mg} / \mathrm{ml}$. The inhibition range of Neem seed extract for all the isolates was 54.2-95.4\%. Neem seed was statistically significant $(\mathrm{p}<0.05)$ only at $100 \mathrm{mg} / \mathrm{ml}$ when compared with Miconazole nitrate.

TABLE 4: PERCENTAGE RADIAL GROWTH INHIBITION OF PICRALIMA NITIDA RIND EXTRACT AGAINST FUNGAL ISOLATES

\begin{tabular}{|c|c|c|c|c|c|c|c|}
\hline \multirow[t]{2}{*}{ Fungal isolates } & \multicolumn{3}{|c|}{ Concentration of Extracts } & \multicolumn{4}{|c|}{$\begin{array}{l}\text { TABLE 7: PERCENTAGE RADIAL GROWTH } \\
\text { INHIBITION OF EUPHORBIA HIRTA LEAF EXTRACT } \\
\text { AGAINST FUNGAL ISOLATES }\end{array}$} \\
\hline & $25 \mathrm{mg} / \mathrm{ml}$ & $50 \mathrm{mg} / \mathrm{ml}$ & $100 \mathrm{mg} / \mathrm{ml}$ & Fungal isolates & \multicolumn{3}{|c|}{ Concentration of Extracts } \\
\hline & \multicolumn{3}{|c|}{ Radial growth inhibition } & & $25 \mathrm{mg} / \mathrm{ml}$ & 50 & $100 \mathrm{mg} / \mathrm{ml}$ \\
\hline T.soudanense & $92.3 \%$ & $95.4 \%$ & $100 \%$ & & & \multicolumn{2}{|c|}{$\mathrm{mg} / \mathrm{ml}$} \\
\hline T.mentagrophytes & $80 \%$ & $94 \%$ & $100 \%$ & \multirow{3}{*}{$\begin{array}{l}\text { T.soudanense } \\
\text { T.mentagrophytes }\end{array}$} & \multicolumn{3}{|c|}{ Radial growth inhibition } \\
\hline Cladosporium sp & $86.7 \%$ & $91.7 \%$ & $100 \%$ & & \multirow{2}{*}{$0 \%$} & \multirow{2}{*}{$40 \%$} & \multirow{2}{*}{$100 \%$} \\
\hline T.rubrum & $94 \%$ & $94 \%$ & $100 \%$ & & & & \\
\hline Fusarium $\mathrm{sp}$ & $90.6 \%$ & $94.1 \%$ & $100 \%$ & Cladosporium sp & $0 \%$ & $33.3 \%$ & $100 \%$ \\
\hline & & & & T.rubrum & $0 \%$ & $60 \%$ & $100 \%$ \\
\hline & & & & Fusarium sp & $-5.9 \%$ & $35.3 \%$ & $100 \%$ \\
\hline
\end{tabular}
shown in Table 5 had its highest antifungal effect of $100 \%$ RGI at $100 \mathrm{mg} / \mathrm{ml}$. All investigated isolates were completely inhibited at $100 \mathrm{mg} / \mathrm{ml}$ by the extract except for Cladosporium sp with a PRGI of
$91.7 \%$. T.rubrum had a PRGI of $88-100 \%$ and appeared to be the most sensitive followed by T.soudanense with a PRGI of 76.9-100 \%. The percentage inhibition range of A.occidentale extract for all the isolates was between $23.5-100 \%$ giving a significant difference $(p<0.05)$ on all the concentrations with respect to the standard control (Table 6),

\section{TABLE 5: PERCENTAGE RADIAL GROWTH INHIBITION OF AZADIRACHTA INDICA SEED EXTRACT AGAINST FUNGAL ISOLATES}

\begin{tabular}{llll}
\hline Fungal isolates & \multicolumn{3}{l}{ Concentration of Extracts } \\
& $25 \mathrm{mg} / \mathrm{ml}$ & $\begin{array}{l}50 \\
\mathrm{mg} / \mathrm{ml}\end{array}$ & $100 \mathrm{mg} / \mathrm{ml}$ \\
\hline \multicolumn{3}{c}{ Radial growth } \\
& $86.2 \%$ & $95.4 \%$ & $89.2 \%$ \\
T.soudanense & $\mathbf{8 6} \%$ & $94 \%$ & $94 \%$ \\
T.mentagrophytes & $64 \%$ & $66.7 \%$ & $91.7 \%$ \\
Cladosporium $\mathrm{sp}$ & $54.2 \%$ & $94 \%$ & $95 \%$ \\
T.rubrum & $94 \%$ & $79.4 \%$ & $89.4 \%$ \\
Fusarium sp & $88.2 \%$ & & \\
\hline
\end{tabular}

TABLE 6: PERCENTAGE RADIAL GROWTH INHIBITION OF ANACARDIUM OCCIDENTALE LEAF (CASHEW) SEED EXTRACT AGAINST FUNGAL ISOLATES

\begin{tabular}{llcl}
\hline Fungal isolates & \multicolumn{3}{c}{ Concentration of Extracts } \\
& $25 \mathrm{mg} / \mathrm{ml}$ & $50 \mathrm{mg} / \mathrm{ml}$ & $100 \mathrm{mg} / \mathrm{ml}$ \\
& \multicolumn{3}{l}{ Radial growth inhibition } \\
\hline T.soudanense & $76.9 \%$ & $84.6 \%$ & $100 \%$ \\
T.mentagrophytes & $68 \%$ & $82 \%$ & $100 \%$ \\
Cladosporium $\mathrm{sp}$ & $43.3 \%$ & $80 \%$ & $91.7 \%$ \\
T.rubrum & $88 \%$ & $92 \%$ & $100 \%$ \\
Fusarium $\mathrm{sp}$ & $23.5 \%$ & $52.9 \%$ & $100 \%$ \\
& & & \\
\hline
\end{tabular}

In table 7, Euphorbia hirta exhibited its highest antifungal effect at $100 \mathrm{mg} / \mathrm{ml}$ by completely inhibiting all the fungal isolates. No inhibition was 
observed in most of the isolates under investigation at $25 \mathrm{mg} / \mathrm{ml}$. T.rubrum appeared to be the most sensitive fungi with a PRGI of $60 \%$ at $50 \mathrm{mg} / \mathrm{ml}$ and $100 \%$ at $100 \mathrm{mg} / \mathrm{ml}$. However, the concentrations of $25 \mathrm{mg} / \mathrm{ml}, 50 \mathrm{mg} / \mathrm{ml}$ and 100 $\mathrm{mg} / \mathrm{ml}$ had a significant difference of $(\mathrm{p}<0.05)$ when compared with the Standard. In Table 8, Jatropha curcas exhibited its highest antifungal effect of $100 \%$ at $100 \mathrm{mg} / \mathrm{ml}$ by inhibiting all tested isolates except for Fusarium sp. Mild inhibition of $58.3 \%$ was observed at $25 \mathrm{mg} / \mathrm{ml}$ and $50 \mathrm{mg} / \mathrm{ml}$ for Cladosporium sp. Others appeared to be resistant at these concentrations.

\begin{tabular}{|c|c|c|c|}
\hline \multicolumn{4}{|c|}{$\begin{array}{l}\text { TABLE 8: PERCENTAGE RADIAL GROW } \\
\text { INHIBITION OF JATROPHA CURCAS LEAF E } \\
\text { AGAINST FUNGAL ISOLATES }\end{array}$} \\
\hline Fungal isolates & $25 \mathrm{mg} / \mathrm{ml}$ & $50 \mathrm{mg} / \mathrm{ml}$ & $100 \mathrm{mg} / \mathrm{ml}$ \\
\hline \multicolumn{4}{|c|}{ Radial Growth Inhibition } \\
\hline T.soudanense & $38.5 \%$ & $53.8 \%$ & $100 \%$ \\
\hline T.mentagrophytes & $10 \%$ & $20 \%$ & $100 \%$ \\
\hline Cladosporium sp & $58.3 \%$ & $58.3 \%$ & $100 \%$ \\
\hline T.rubrum & $30 \%$ & $40 \%$ & $100 \%$ \\
\hline Fusarium sp & $29.4 \%$ & $47.1 \%$ & $97.1 \%$ \\
\hline \multicolumn{4}{|c|}{$\begin{array}{l}\text { TABLE 9: PERCENTAGE RADIAL GROWTH } \\
\text { INHIBITION OF ACANTUS MONTANUS LEAVES } \\
\text { EXTRACT AGAINST FUNGAL ISOLATES }\end{array}$} \\
\hline \multirow[t]{2}{*}{ Fungal Isolates } & \multicolumn{3}{|c|}{ Concentration of extracts } \\
\hline & $25 \mathrm{mg} / \mathrm{m}$ & $\begin{array}{l}50 \\
\mathrm{mg} / \mathrm{ml}\end{array}$ & $100 \mathrm{mg} / \mathrm{ml}$ \\
\hline \multicolumn{4}{|c|}{ Radial Growth inhibition } \\
\hline T.soudanense & $84.6 \%$ & $92.3 \%$ & $100 \%$ \\
\hline T.mentagrophytes & $52 \%$ & $64 \%$ & $100 \%$ \\
\hline Cladosporium sp & $50 \%$ & $66.7 \%$ & $100 \%$ \\
\hline T.rubrum & $-40 \%$ & $0 \%$ & $100 \%$ \\
\hline Fusarium $\mathrm{sp}$ & $41.2 \%$ & $52.9 \%$ & $100 \%$ \\
\hline
\end{tabular}

Cladosporium sp appeared to be the most sensitive fungi with a PRGI of 58.3-100\%. The extract was significantly higher $(\mathrm{p}<0.05)$ at the three concentrations with respect to the standard. In Table 9 shows that Acanthus montanus at 100 $\mathrm{mg} / \mathrm{ml}$ exhibited its highest antifungal effect by completely inhibiting all the tested isolates at a100 $\%$ RGI. T.rubrum and Fusarium sp were not inhibited at $25 \mathrm{mg} / \mathrm{ml}$ and $50 \mathrm{mg} / \mathrm{ml}$ of extract. T.soudanense appeared to be the most sensitive with a PRGI of 84.6-100 \% followed by
T.mentagrophytes with PRGI of 52-100\%. However, there was a significant difference $(\mathrm{p}<$ 0.05 ) in activities of the plant extract to the standard. The phytochemical studies of these plants revealed the presence of secondary metabolites such as tannins, terpenoids, alkaloids, flavonoids, phenols, steroids, glycosides and volatile oils (Table 10).

\section{TABLE 10: PHYTOCHEMICAL CONSTITUENTS OF CHLOROFORM EXTRACT}

\begin{tabular}{llc}
\multicolumn{2}{c}{ CHLOROFORM EXTRACT } \\
\hline S/No & Phytoconstituent & CE \\
\hline 1 & Alkaloids & + \\
2 & Carbohydrates & + \\
3 & Flavonoids & - \\
4 & Glycosides & - \\
5 & Fats and oil & - \\
6 & Tannins & - \\
7 & Saponins & - \\
8 & Resins & + \\
9 & Proteins & - \\
10 & Terpenoids & \\
11 & Steroids & \\
\hline Key: + & & \\
& &
\end{tabular}

\section{DISCUSSION AND CONCLUSION}

The methanolic extracts of six different plant species were assayed for antifungal activities and compared with Miconazole nitrate using the agar plate method. Miconazole belong to the azole group of antifungal agents used clinically against fungal infections. They owe their antifungal activity by inhibiting the enzyme lanosterol 1,4-a-demethylase; the enzyme necessary to convert lanosterol to ergosterol, which is the predominant sterol in fungal cell membranes responsible for maintaining cell integrity, viability, function and normal growth [16]. Results from this study showed that the methanolic extract of Picralima nitida (seed and rind), Azadirachta indica (Neem), Anacardium occidentale (Cashew), Euphorbia hirta, Acantus montanus and Jathropha curcas exhibited antifungal activity against T. soudanense, T.mentagrophyte, T. rubrum, Cladosporium sp and Fusarium sp. These plants were considered to possess biochemically related substances with similar inhibitory properties with miconazole with the antifungal activities varying differently at the same concentrations of each of the extracts against the 
respective fungal isolate. It generally increases with increase in concentration of the extracts. This finding agrees with other study [17], which showed higher concentrations of antimicrobial substances led to appreciable growth inhibition.

The phytochemical studies of these plants also reveal the presence of secondary metabolites such as tannins, terpernoids, alkaloids, flavonoids, phenols, steroids, glycosides and volatile oils (Table 10). The antifungal activities of these plants may probably be due to the presence of these rich secondary metabolites in plants which is tandem with other studies $[18,19,20]$. The patterns of radial growth inhibition of these plant extracts in this study were similar to those of miconazole nitrate. This could suggest the presence of similarly active ingredients present in Miconazole nitrate (the control antifungal agent) which is used predominantly as a drug of choice against superficial fungal infection especially Trichophyton spp, Epidermophyton spp and Micosporium spp. The activities of Picralima nitida seed extract appeared to be better than the other plant extracts investigated. This could be based on the concentration of active antifungal ingredients such as the phenolics (Tannins and flavonoids) present in that part of the plant material. The activities of Picralima nitida (seed and rind) in this study justifies its use in the treatment of skin conditions including of Tinea corporis (ringworm of the skin), Tinea capitis (ringworm of the head) as reported by other works [21, 22]. Azadirachta indica (Neem) seed oil has been used in the treatment of various skin infections by alternative system of medicine [23]. Its activities in this study are in agreement with the work done [24], where neem oil was shown to have different inhibitory effects on different fungi including $T$. rubrum, T. mentagrophytes and Fusarium sp. However, though there was no complete inhibition observed in this study with any of the fungi, which could be due to neem oil from different localities may possess different rates of the antifungal activities with significant effect on all the fungal species tested. This variation could be due to the difference in the quality of the active ingredients in the oil sample. The leaves of Anacardium occidentale (cashew) in this study exhibited poor inhibitions at lower concentrations, though Rajesh et al [25] reported that, the nuts have proven antifungal properties of more than $94 \%$ inhibition against Aspergillus fumigatus, A niger, Curvalaria sp and Fusarium sp. This is an indication of uneven distribution of the active ingredients of the plant. Euphorbia hirta exhibited resistance at lower

\section{REFERENCES}

1. Svetaz, L., Zuljan, F. and Derita, M.. Value of the ethnomedical information for the discovery of plants with antifungal properties. A survey among seven Latin American countries. Journal concentrations on some of the isolates, but complete inhibition at a higher concentration. This finding agrees with the other findings [9], as sensitivity increases with increase in concentration. Jatropha curcas in this study showed a poor inhibition of 10 $\%$ and $30 \%$ at $25 \mathrm{mg} / \mathrm{ml}$ for T. mentagrophytes and T.rubrum respectively. However, Adejumo et al. 2009 who worked on Fusarium sp observed it to be the most resistant. The difference in their susceptibilities could be attributed to an inherent resistance factor of the test organisms among other factors, though other studies [26, 27] observed that, the leaves of Jatropha curcas had no inhibitory effect against T. mentagrophytes rather it was observed in the seed extract. This discrepancy is likely due to the fact that no two plants of the same species may have experienced the same environmental challenges considering the fact that plants phytoanticipins are uniformly distributed within the plants while phytoalexins are restricted to the tissue colonized by the fungus and the cells surrounding the infection site [28]. Some antifungal compounds may be present constitutively in one part of a plant, but induced as phytoalexins in other organs. Acantus montanus had not really been widely used in folk medicine for the treatment of skin diseases, rather for pain, inflammation and other ailments $[29,30]$. Its antifungal activities in this study support its usage in folklore treatment. T.rubrum and T.soudanense appear to be the most sensitive fungi at lower concentrations of the extracts. This could be due to the difference in the concentrations of the bioactive components in the sample or synergistic reactions of the various phytochemicals in the extract.

Euphorbia hirta (Asthma weed), Anacardium occidentale L (Cashew), Picralima nitida (Akuamma plant), Jatropha curcas (Barbados nut), Azadirachita indica A (Neem plant), and Acantus montanus (Mountain thistle) have antifungal activities. Their antifungal activities increase with increase in concentrations. Crude extract of Picralima nitida seed possesses the highest antifungal activity. The phytochemistry of its chloroform fraction reveals the presence of flavonoids, alkaloids and terpenoids. Trichophyton rubrum was the most sensitive fungal under investigation. Further investigation of the purified components of the seed extracts of Picralima nitida to determine the metabolites responsible for their activities will make it serve as a good base for consideration in the pharmaceutical industries for the production and packaging of antifungal products.

of Ethnopharmacology. (2010)127 (1):137158.

2. Demetrio LV, Jeanie IA, Juliana Janet MP, Esperanza CC,Windell L. Antibacterial activities of ethanol extracts of Philippine medicinal plants against multidrug-resistant bacteria Asian Pacific 
Journal of Tropical Biomedicine, (2015), Volume 5, Issue 7.

3. Farnsworth, N.R.Screening plants for new medicine In: Wilson, E.O.(Ed), Biodiversity. Part 11. National Academy Press, Washington. (1989) 88-97.

4. Leena, T. and Jaindranath,T.. Tropical Journal of Pharmaceutical Research. (2003) 2(2): 243-253.

5. World Health Organization, (2002). Traditional medicine strategy. 2002-2005.

6. Ame, I.O, and Salah, E.I. Therapeutic utility constituents and toxicity of some medicinal plants. Veterinary and Human Toxicology. (1995) 37(3):46.

7. Hammer, K.A., Carson, C.F., Riley,T.V. Antimicrobial activity of essential oils and other plant extracts. Journal of Applied Microbiology. (1999) 86(6): 985.

8. Owoyale, J.A., Olatunji, G.A., Oguntonye, S.O. Antifungal and antibacterial activities of an Alcoholic Extract of Senna alata leaves. Journal of Applied Sciences and Enviromental Management, (2005) 9(3): 105-107.

9. Momoh, A.R.M., Idonije, O.B., Okhai, O., Iribhogbe, O.I., Momoh, A.A., Otamere, H.O., Ekhator, C.N., Okolo, P.O., Oseghale, D.A. The Antifungal Effects of Extract of Euphorbia hirta on selected Pathogenic fungi. New York Science Journal, (2011). 4(80).

10. Timothy, S.Y., Goji, S.Y., Abdusallam, B., Mava,Y. and Galadima, I.H. Antibacterial and Phytochemical screening of the ethanolic leaf extract of Azadirachta indica (Neem). International Journal of Applied Biology and Pharmaceutical Technology. (2011) 2:194.

11. Tejas, G., Mayank, Patel.and Bharat, k. D. Scholars Research Library. Journal of National production and plant resource. (2012) 2(1): 135-142.

12. Oseni ,L., Adebayo, Alphonse, Prince Kofi. Comparism of antibacterial properties of solvent extracts of different parts of Jatropha curcas (linn). International Journal of Pharmaceuticals and Phyto Pharmacological Research. (2011) 1(3): 117 - 123.

13. Vinit, K. M. In vitro antagonism of Trichoderma species against Pythium Aphanidermatum. Journal of Phytology, (2010) 2(9): 28-35.

14. Geetu, G. Chromatography (A Refresher Course CPDHE) (2008) on Sivaprakasan, K., and Vidhyasekran,P.,(1993). Phenylalanine ammonia lyase gene for crop management.In: Vidhyasekaran, P. ed. Genetic Engineering, Molecular Biology and Tissue Culture for Crop, Pest and Disease Management. Delhi, India. pp: 113-122.
15. Trease, G. E and Evans, N. C. Textbook of Pharmacognosy $15^{\text {th }}$ edition. W.B.Saunders Company Ltd, London,(1996).168:249-251.

16. Ghannoum, M.A., and Rice, L.B. Antifungal agents: Mode of action, Mechanisms of Resistance, and Correlation of these mechanisms with bacterial resistance. Clinical Microbiology Review. (1999) 12: 501-517.

17. Banso, A., Adeyemo, S.O., Jeremiah, P. Antimicrobial properties of Vernonia amygdalina extract. Journal of Applied Science and Management (1999) (3):9-11.

18. Baba-Moussa, F. and Akpagana, K.B. Antifungal activities of Seven West African Combretaceae used in Traditional Medicine. Journal of Ethnopharmacology, (1999) 66(3):335-338.

19. Cowan, M.M.A Plants Products as Antimicrobial Agents. Clinical Microbiology Review. (1999) 12:564-582.

20. Reyes-Chilpa, Garibay,M.T., JimenezEstrada and Quiroz-Vasquez. Flavonoids and Isoflavonoids with Antifungal properties from Platymiscium yucatanum heartwood Holzforschuna. International Journal of Biological, Chemical and Physical Technology Wood (2009) pg 52.

21. Wosu,L.O., and Ibe,C.C. Use of extract of Picralima nitida bark in the treatment of experimental trypanosomiasis: A preliminary Study. Journal of Ethnopharmacology (1989) 25:263-268.

22. Ezeamuzieji, C., Ojiamaka, M.C., Uzogara, E.O. and Orji, S.E. Antiinflammatory, Anti-pyretic and Antimalarial activities of a West African Medicinal Plant Picralima nitida. African Journal of Medical Sciences (1994) 23:85-90

23. Natarajan, V., Venugopal, P.V., and Menon, T. Effect of Azadirachta indica (Neem) on the growth pattern of Dermatophytes. Indian Journal of Medical Microbiology (2003) 21(2):98-101.

24. Khan, M., and Wassilew, S.W. Natural Pesticides from the Neem Tree and Other Tropical Plants (eds Schutterer, H. and Asher, K.R.S.), GT2, Eschborn, Germany, (1987) pp 645-650.

25. Rajesh, K., Verma, L.C., and Sadhana, K. Potential antifugal plants for controlling building fungi. Natural Product Radiance. (2007) 7(4):374-387.

26. Ayanbimpe, G.M and Fagbemi, O.I. Antifungal activity of extracts from a hedges plant Jatropha curcas on some pathogenic fungi. Nigerian Annals of Natural Sciences. (2005) 6(1):18 - 22.

27. Ekpo, M.A. and Etim, P.C. Antimicrobial activity of ethanolic and aqueous extracts of Sida acuta on microorganisms from 
skin infections. Journal of Medical and Plants Research. (2009) 3 (9):621-664.

28. Dixon, R. Natural products and plant disease resistance. Nature. (2001) 411: 843847.

29. Asongalem, E.A., Nana, P., Foyet, H.S., Dimo, T., Kamtchouing, P. Antifertility and fetotoxic activities of Acantus montanus extracts in Wister rats. Pubmed
Clinical Pharmacology, (2008) 30(7): 521528.

30. Adejumo, T.O and Bamidele, B.S. Control of dermatophyte-causing agent (Trichophyton mentagrophytes and Trichophyton rubrum) using six medicinal plants. Journal of Medicinal Plant Research (2009): 3(11):906-913. 